\title{
A visual knowledge map analysis of mine fire research based on Citespace
}

\section{Feiran Wang}

China University of Mining and Technology Beijing Campus

\section{Bo Tan ( $\square$ tanbo709@126.com )}

China University of Mining and Technology Beijing Campus https://orcid.org/0000-0001-5867-9595

\section{Yue Chen}

China University of Mining and Technology Beijing Campus

\section{Xiyang Fang}

China University of Mining and Technology Beijing Campus

\section{Guowei Jia}

The Administrative Center for China's Agenda 21

\section{Haiyan Wang}

University of Science and Technology Beijing

\section{Gang Cheng}

China University of Mining and Technology Beijing Campus

\section{Zhuangzhuang Shao}

China University of Mining and Technology Beijing Campus

\section{Research Article}

Keywords: Coal fire, Citespace, Coal spontaneous combustion, Visual analysis

Posted Date: February 22nd, 2022

DOI: https://doi.org/10.21203/rs.3.rs-1259291/v1

License: (c) (1) This work is licensed under a Creative Commons Attribution 4.0 International License.

Read Full License 


\section{Abstract}

Mine fire has always been a serious disaster in coal industry, many academic achievements have poured out in the past two decades for solving this problem. In this study, visual analysis was conducted to grasp the hotspots and development trend of mine fire research. Papers that published in 1999-2020 were retrieved as the data basis from Web of Science, and Citespace was used to carry out knowledge map analysis. The results shown that number of papers has increased steadily since 2005 and achieved explosive growth since 2014. DENG $\mathrm{J}$ is the first published author among many scholars. China, the US, Australia are active areas in mine fire research and China University of Mining and Technology ranks first in this field. The highest co-occurrence frequency key word is "spontaneous combustion". "INTERNATIONAL JOURNAL OF COAL GEOLOGY" and "FUEL" provide guidance for mine fire research. Fire prevention technology, low carbon, ecology and sustainable development are the hot research in recent years.

\section{Introduction}

Nearly $90 \%$ coal mines in China adopt the well exploitation. The mining depth increase and the complex hydrogeological conditions of coal mines leads to a great threat for the coal mine. Mine fire produces a large number of toxic gases and smoke, which diffuses to the whole mine by air flow through the ventilation network. It is easy to reach the location far from the fire source and to cause wind reversal, which aggravates the miner's risk. Although the fire-related injuries and death decrease in the past few years, mine fires still pose a threat to the miners' safety.

So far, a large number of scholars and experts have done a lot of research on mine fire. The research content is wide and diverse, however, the sorting out of present achievements is few. Most of the traditional visualization methods involve explore and interpret the existing data by analysts. It uses people's vision and knowledge reserve to seek information, which has limitations and omissions inevitably. In the information explosion age, people are no longer satisfied with the traditional visualization method, which only reflects the surface information of data. The present visual analysis method helps us seeking data in high efficiency and evaluating the current research object progress, which discovers the following research direction and new rules.

Knowledge map has widely use in fires. Li. (2016) studies the characteristics and evolution of the structure of safety science by taking the scientific and technological texts accumulate for a long time as the research object. Based on Citespace, the application of FDS software in the field of fire simulation is analyzed. Lin et al. (2020), Fu et al. (2020) and other researchers (He et al., 2019; Cui et al., 2019; Wang et al., 2016) conduct visual analysis on FDS fire simulation, gas explosion, fire numerical simulation, forest fire and other fields based on Citespace software. Jin et al. (2019) uses VOSviewer to catch visual research on building safety. Citespace shows the evolution of a knowledge field on a network map, and is one of the most popular drawing tools of knowledge map Chen et al. (2015). Therefore, in order to analyze the dynamic, polymorphic and multi-source data in the field of mine fire, this paper uses 
Citespace software to draw knowledge map from the perspectives of publication distribution, authors, institutions, countries and keywords, in order to provide valuable information for the academic research and development in this field.

\section{Research Method}

\subsection{Citespace summarize}

CiteSpace is a multi-view information visualization software based on Java platform developed by Chinese American bibliometrics professor Chen Chaomei in 2004. The main function is to show the evolution trend and knowledge association of the science frontier through the visualization analysis. Citespace transforms the data exported from the WOS database to draw various knowledge maps and display the research field details by node size, network connectivity and other factors Liu. (2020). Besides the wide range of applications, the algorithm and data mining function in Citespace is powerful that other software does not have, such as: Minimum spanning tree algorithm, path network simplification algorithm and expansion word mutation detection algorithm. They provide users with rigorous analysis process and accurate results of the map. This paper uses the visual bibliometric analysis tool Citespace 5.8.R3 to process and analyze the data.

\subsection{Using and debugging}

Users create a new project in Citespace and named "Mine Fire", importing data, and setting parameters. In the main screen, the settings of Citespace interface includes time zone division, node type, connection, threshold setting, path selection, and map generation description. In particular, the Time Slicing is to segment the time zone of the data to be analyzed. The analysis time in this paper is set as 1999-2020, and the Time Slicing is 1 year. The Text Processing is used to select the Term extraction location and supplementary selection of common word analysis types. Network configuration area includes Node Types, Links, and Selection Criteria and the Network types depends on the analysis object. Different nodes generate different types and functions networks. Author, Institution and Country generate cooperation map. Term and Keyword produce the corresponding network. Cited Reference, Cited Author, Cited Journal is a co-cited network analysis of guiding papers, authors and source journals, respectively. Threshold selection includes four algorithms and they are Top $\mathrm{N}$ per slice, Top N\% per slice, Threshold Interpolation and Select Citers.

Pruning parameters and functional areas work for the network Pruning, including PFNET (Path finding network) and MST (Minimum Spanning Tree) algorithms. Both of them are used to cut the connections in the network for the network density reduction and the network readability improvement. Finally, Visualization is adopted to set up Visualization results, including Cluster View, Timezone View and Timeline View.

\section{Database}




\subsection{Data selection}

Based on the research object and characteristics, all the data and information are from the Web of Science core database of ISI, which has the most authoritative data source in the world at present. It has more than 5500 kinds of scientific journals in this database. WOS contains the most influential and highquality journal paper from all over the world, which ensures the accuracy of the data in this paper.

\subsection{Data collection and processing}

With the Web of Science Core Collection and the topic of "Mine Fire or Coal Spontaneous Combustion", 5181 papers are conducted from 1999 to 2020 . 3048 papers are obtained by further refining the retrieval results. The data are imported into Citespace then 1334 papers are visualized through the de-merging and screening functions of the tool. "Pathfinder" is used to analyze author, institution, keyword, journal, country, citation and other contents, so as to obtain the corresponding knowledge map. Finally, measurement visualization analysis, tables and other tools, owned by WOS, are adopted to supplement and improve.

\section{Data Analysis}

\subsection{Number of articles in different periods}

The paper quantity is an important parameter to measure the quality in a certain field, which reflects the research results and active degree in a certain subject. By analyzing the temporal distribution and cumulative output of papers, it judges the social and academic attention degree to this field, which reveals the academic research and development trend Xue et al., (2020). Fig. 1 shows the amount of mine fire published in WOS from 1999 to 2020, presenting an obvious upward trend on the whole. In the initial period (1999-2005), the number of papers published in 1999 is Fig. 1. The possible reason is that due to the poor communication technology at that time, all papers cannot be uploaded. After that, with the rapid development of economy and the popularization of the Internet, the article number published begin to rise slowly. In stable transition period (2005-2014), the annual average number of papers published is about 28. The number of published papers increases from 68 in 2014 to 267 in 2020, which lies in booming growth period (2014-2020) (Tan et al., 2020a; Tan et al., 2019; Tan et al., 2020b; Tan et al., 2020c; Zhu et al., 2020). During this period, the academic community's understanding of mine fire rise to a new height, and the study of mine fire is still developing vigorously.

\subsection{Author analysis}

\subsubsection{Author publication statistics}

When analyzing the number of papers published by 682 authors, prolific authors are the analysis focus. Prolific authors are those who publish more papers in a certain field. According to Price's law, the specific formula is. 
$\mathrm{M}=0.794 \times \sqrt{N_{\max }}(1)$

Where $M$ represents the minimum number of core authors in a certain field, and $N_{\max }$ represents the maximum number of core authors in a certain field. According to Price's law, the author who has a high number of papers includes DENG J, SHU CM, QIN BT, WANG DM, ZHU HQ. DENG J has published a large number of papers from 2015 to 2020 , making great contributions to the research on mine fire. DENG J mainly engages in the theory and technology research of coal fire disaster prevention and control. In recent years, he has made a series of achievements in scientific issues such as nature of coal spontaneous combustion, characteristic information identification of coal spontaneous combustion and coal fire disaster prevention, which has published a lot of highly cited papers (Deng et al., 2015; Deng et al., 2016; Xiao et al., 2018; Deng et al., 2018; Deng et al., 2017). SHU CM, from National Yunlin University of Science \& Technology, mainly studies the whole process of primary and secondary spontaneous combustion of coal and publishes some valuable papers from 2017 to 2020 (Zhao et al., 2019; Wang et al., 2016; Deng et al., 2017; Liu et al., 2015).

\subsubsection{Author cooperation relationship}

WOS paper data is imported into Citespace, setting the time span to 1999-2020 and time slice to 1 year. "Author" is chosen as "Node Types" analysis content after format transformation. Path algorithm conducts keyword frequency analysis for "Pathfinder, Pruning networks, pruning the merged network". Thus, an author collaboration map of "Nodes $=682$ ", "Links $=797$ " and "Density $=0.0031$ " is obtained.

In Fig. 2, the author cooperation map of mine fire presents a relatively close distribution on the whole. On the left is a large cluster formed by four groups WANG DM, QI GS, PAN RK and YANG SQ, and on the right it is a small cluster represented by SHU CM (Lu et al., 2019; Lu et al., 2021; Luo et al., 2022; Pan et al., 2020). WANG DM and QIN BT, DOU GL, LI XB, LU XX, DONG SJ, SHI GQ, WANG YM, WANG Y, HU C, MA LY (Qin et al., 2018; Ma et al., 2017; Zhang et al., 2021; Yuan et al., 2018; Wen et al., 2020; Zhang et al., 2019; Sun et al., 2019; Li et al., 2020; Shao et al., 2018; Lee et al., 2020; Yan et al., 2019; Du et al., 2018) are a small team of 10 people. Most of them are from China University of Mining and Technology, Henan Polytechnic University, China University of Mining and Technology (Beijing), Xi 'an University of Science and Technology, etc. The internal cooperation among institutions represented by China University of Mining and Technology indicates that the academic research teams engage in mine fire research in China have gradually become mature, and academic exchanges between authoritative authors play a key role in the research of this field.

In addition, QI GS cooperates with LIANG YT, LI JL and QI XY frequently. PAN RK is closely associated with HU DM, WU MY, MA JW and WANG J. YANG SQ has a cooperative relationship with TANG ZQ, CAI JW and SONG WX (Cai et al., 2019; Xu et al., 2019; Song et al., 2019). SHU CM is closely related to four authors, WANG CP, DENG J, ZHAO JY, and ZHANG YN. This means that there are many scholars studying mine fire in the world, but most of their researches are scattered and there is no large-scale cooperation and exchange behavior. Most of them are organized in the form of small groups of three or four people. Therefore, the large-scale cooperation among authors in the mine fire field research needs to be 
strengthened. At present, the cooperation between authors is affected by regional, economic, linguistic and cultural factors or other aspects.

\subsubsection{Authors co-citation}

Authors co-citation analysis refers to the situation where two or more authors are simultaneously cited by other authors' papers, which obtains the distribution of highly cited authors and understands the research topics in the field. On the micro level, it reveals the interweaving and dependence between some disciplines. On the macro level, it reflects the discipline composition and structural characteristics of the scientific system to a certain extent (Zuo et al., 2021).

"Cited Author" is used as "Node Types" and path algorithm is set as "Pathfinder" for Author analysis. Thus, an author co-cited network map of "Nodes $=880$ ", "Links $=3090$ " and "Density (Density) $=0.0051$ " is obtained, as shown in Fig. 3. It can be seen from the map that some co-cited authors cooperate closely. DENG J, WANG HH, STRACHER GB, CARRAS JN and SONG ZY are highly cited authors. In this paper, it is found that DENG $J$ is not only a prolific author, but also a highly cited author. His paper is abundant in quantity and is of good quality as well. WANG HH, from UNIVERSITY OF NEWCASTLE, mainly studies low temperature oxidation of coal Stracher Glenn B. of the University System of Georgia, who studies coal fires. CARRAS JN, from Commonwealth Scientific \& Industrial Research Organisation (CSIRO), has made outstanding contributions in coal spontaneous combustion and $\mathrm{CO}_{2}$ injection into coal seam fire prevention and control. Song ZY is from Xi'an University of Science and Technology and his research focuses on coal field fire, energy and fuel.

Combine with the analysis of prolific authors, it is found that the number of Chinese authors with high citation frequency on the list is significantly reduced. It indicates that Chinese authors have more paper in the mine fire but their citation frequency is not proportional. The citation frequency of an author's paper reflects the author's status and influence in a certain research field. Therefore, Chinese authors need to make efforts in this regard to maintain a high number papers, ensuring the quality of papers and improving their influence in their research.

\subsection{Research institutions analysis}

\subsubsection{Institution publication statistics}

The high-yield institutions with more than 13 publications are selected from 535 research institutions as the main research objects in Table. 1. China Univ Min \& Technol from China ranks the first with 283 papers, with 26, 37, 57, 43, 45 paper distributed in the past five years. WANG DM, KONG B, Xin HH, Xia TQ and others from this institution make significant contributions to the study of mine fire related to threephase foam, coal spontaneous combustion, gas extraction and so on. Meanwhile, 9 of the top 13 institutions in the number of publications are from China, they are China Univ Min \& Technol, Xian Univ Sci \& Technol, China Univ Min \& Technol Beijing, Natl Yunlin Univ Sci \& Technol, Henan Polytech Univ, Shandong Univ Sci \& Technol, Taiyuan Univ Technol, Liaoning Tech Univ, Shaanxi Key Lab Prevent \& 
Control Coal Fire. It is found that Chinese research institutions have conducted extensive research on mine fire, which indicates that Chinese institutions have become effective forces in the mine fire research.

Table 1

Statistics of high-yield institutions' publications

\begin{tabular}{|c|c|c|c|}
\hline Number & Counts & Centrality & Institutions \\
\hline 1 & 283 & 0.09 & China Univ Min \& Technol \\
\hline 2 & 91 & 0.03 & Xian Univ Sci \& Technol \\
\hline 3 & 87 & 0.04 & China Univ Min \& Technol Beijing \\
\hline 4 & 46 & 0.04 & Natl Yunlin Univ Sci \& Technol \\
\hline 5 & 42 & 0.12 & Henan Polytech Univ \\
\hline 6 & 42 & 0.07 & Shandong Univ Sci \& Technol \\
\hline 7 & 37 & 0.25 & Taiyuan Univ Technol \\
\hline 8 & 30 & 0.08 & Liaoning Tech Univ \\
\hline 9 & 26 & 0.00 & Shaanxi Key Lab Prevent \& Control Coal Fire \\
\hline 10 & 23 & 0.01 & Univ Queensland \\
\hline 11 & 21 & 0.01 & Hunan Univ Sci \& Technol \\
\hline 12 & 18 & 0.04 & Monash Univ \\
\hline 13 & 17 & 0.07 & Univ Witwatersrand \\
\hline 14 & 17 & 0.00 & Cent Min Inst \\
\hline 15 & 15 & 0.00 & Selcuk Univ \\
\hline 16 & 15 & 0.12 & Anhui Univ Sci \& Technol \\
\hline 17 & 14 & 0.00 & Indian Sch Mines \\
\hline 18 & 14 & 0.02 & Univ Sci \& Technol Beijing \\
\hline 19 & 14 & 0.01 & Chinese Acad Sci \\
\hline 20 & 13 & 0.01 & Chongqing Univ \\
\hline 21 & 13 & 0.00 & North China Inst Sci \& Technol \\
\hline 22 & 13 & 0.05 & Minist Educ \\
\hline
\end{tabular}

\subsubsection{Institution cooperation relationship}

Citespace is used to determine relevant parameters after several debugging. And generates a cooperation map of research institutions with 535 nodes and 544 links, as shown in Fig. 4. Each node and its size 
represent an institution and cooperation frequency, meanwhile the links between nodes represent the cooperation relationship (Liu et al., 2020). China Univ Min \& Technol establishes the largest node and close cooperation with 15 institutions. For example, China Univ Min \& Technol Beijing, Henan Polytech Univ, Univ Sci \& Technol Beijing and other institutions. This presents a cooperative network radiating outward from the center of China Univ Min \& Technol. In Australia, Univ Queensland, Monash Univ, Curtin Univ, CSIRO Energy CSIRO, Univ Wollongong work closely. Univ Kentucky, NIOSH, Penn State Univ, Morehead State Univ and West Virginia Univ have frequent contact in the United States. It is found that the cooperation between institutions is regional, and the cooperation between countries or continents is rare. Fig. 4 roughly divides the cooperative relationship into three parts. They are the American cooperative network centered on Univ Kentucky, the Chinese cooperative network centered on China Univ Min \& Technol and the Australian cooperative network centered on Univ Queensland.

\subsection{Country analysis}

\subsubsection{Country publication statistics}

According to the statistical analysis of the 94 countries publications, price's law calculation demonstrates that the minimum publications among 11 high-yielding countries is 21, as shown in Table. 2 and Fig. 5. China ranks the top with 678 papers, accounting for $50.82 \%$ and the US ranks second with 140 papers, accounting for $10.49 \%$. From 2 papers in 2008 to 164 papers in 2020, China shows a rapid progress and becomes one of the high-yielding countries in the world. China's research achievements in the mine fire field and the degree of concern far exceeds other countries, which has become the backbone of all countries in this field. The US has been publishing papers on mine fires since 1999, which is a pioneer in the field. The number of papers, published in 2018, is 15 at most. Other high-yielding countries include Australia, India, Poland, South Korea, Turkey, Canada, Spain, etc. It is concluded that all high-yielding countries in mine fire are also recognized as big coal producers in the world. 
Table 2

Statistics of high-yielding country publications

\begin{tabular}{|llll|}
\hline Number & Counts & Centrality & Country \\
\hline 1 & 678 & 0.25 & PEOPLES R CHINA \\
\hline 2 & 140 & 0.58 & USA \\
\hline 3 & 103 & 0.31 & AUSTRALIA \\
\hline 4 & 58 & 0.18 & INDIA. \\
\hline 5 & 46 & 0 & POLAND \\
\hline 6 & 27 & 0 & SOUTH KOREA \\
\hline 7 & 27 & 0.03 & TURKEY \\
\hline 8 & 26 & 0.06 & CANADA \\
\hline 9 & 25 & 0.3 & SPAIN \\
\hline 10 & 24 & 0.17 & SOUTH AFRICA \\
\hline 11 & 21 & 0.5 & GERMANY \\
\hline
\end{tabular}

\subsubsection{Country cooperation relationship}

By using Citespace and adjusting parameters, the map of national research cooperation with 94 nodes and 116 links is obtained, as shown in Fig. 6. Nodes and its size represent countries and the cooperation frequency, meanwhile the line between nodes represents cooperation relationship (Xu et al., 2021). The USA has cooperative relations with 10 countries, such as PEOPLES R CHINA, NETHERLANDS, PERU, MEXICO, CANADA, PAKISTAN, etc. PEOPLES R CHINA has close cooperation with the USA, NORTH IRELAND and SOUTH KOREA. AUSTRALIA has close contact with PAKISTAN, U ARAB EMIRATES, GERMANY and SWEDEN. As two high-yielding countries, China and Australia carry out independent research and their cooperation intensity with other countries is much lower than that of the US.

\subsection{Journal co-citation analysis}

Taking "Cited Journal" as the analysis content and path algorithm as "Pathfinder" for author analysis, a Journal co-citation map of "Nodes $=814$ ", "Links $=2937$ " and "Density $=0.0089$ " is obtained, shown in Fig. 7. In addition, "Generate a Narrative" in "Export" is used to obtain an arrangement list of cited journals. The top 10 journals are listed, as shown in Table. 3 and Table. 4. 
Table 3

Top ten cited journals ranking table

\begin{tabular}{|lll|}
\hline Counts & Centrality & Cited journal \\
\hline 535 & 0.07 & INT J COAL GEOL \\
\hline 512 & 0.05 & FUEL \\
\hline 339 & 0.02 & SCI TOTAL ENVIRON \\
\hline 286 & 0.05 & ENVIRON SCI TECHNOL \\
\hline 269 & 0.04 & SCIENCE \\
\hline 240 & 0.04 & NATURE \\
\hline 240 & 0.07 & FUEL PROCESS TECHNOL \\
\hline 223 & 0.03 & J HAZARD MATER \\
\hline 221 & 0.01 & ATMOS ENVIRON \\
\hline 213 & 0.01 & J LOSS PREVENT PROC \\
\hline
\end{tabular}


Table 4

Detailed information of highly cited journals

\begin{tabular}{|c|c|c|c|c|c|}
\hline Abbreviation & $\begin{array}{l}\text { Publishing } \\
\text { country }\end{array}$ & $\begin{array}{l}\text { Primary } \\
\text { classification }\end{array}$ & $\begin{array}{l}\text { Secondary } \\
\text { classification }\end{array}$ & $\begin{array}{l}\text { Average IF } \\
(2019 \sim 2021)\end{array}$ & $\begin{array}{l}\text { Citation } \\
\text { frequency } \\
(2020- \\
2021)\end{array}$ \\
\hline \multirow[t]{2}{*}{$\begin{array}{l}\text { INT J COAL } \\
\text { GEOL }\end{array}$} & \multirow[t]{2}{*}{ Netherlands } & \multirow[t]{2}{*}{$\begin{array}{l}\text { Engineering } \\
\text { technology Q2 }\end{array}$} & $\begin{array}{l}\text { Energy and Fuels } \\
\text { Q2 }\end{array}$ & \multirow[t]{2}{*}{5.051} & \multirow[t]{2}{*}{27351} \\
\hline & & & Geoscience Q1 & & \\
\hline \multirow[t]{2}{*}{ FUEL } & \multirow[t]{2}{*}{ Netherlands } & \multirow[t]{2}{*}{$\begin{array}{l}\text { Engineering } \\
\text { technology Q2 }\end{array}$} & $\begin{array}{l}\text { Energy and Fuels } \\
\text { Q2 }\end{array}$ & \multirow[t]{2}{*}{5.205} & \multirow[t]{2}{*}{137125} \\
\hline & & & $\begin{array}{l}\text { Engineering: } \\
\text { Chemical } \\
\text { Engineering Q2 }\end{array}$ & & \\
\hline $\begin{array}{l}\text { SCI TOTAL } \\
\text { ENVIRON }\end{array}$ & Netherlands & $\begin{array}{l}\text { Environmental } \\
\text { Science and } \\
\text { Ecology Q2 }\end{array}$ & $\begin{array}{l}\text { Environmental } \\
\text { Science Q2 }\end{array}$ & 5.584 & 232429 \\
\hline \multirow{2}{*}{$\begin{array}{l}\text { ENVIRON } \\
\text { SCI } \\
\text { TECHNOL }\end{array}$} & \multirow[t]{2}{*}{$\begin{array}{l}\text { The United } \\
\text { States }\end{array}$} & \multirow{2}{*}{$\begin{array}{l}\text { Environmental } \\
\text { Science and } \\
\text { Ecology Q1 }\end{array}$} & $\begin{array}{l}\text { Engineering: } \\
\text { Environment Q2 }\end{array}$ & \multirow[t]{2}{*}{7.222} & \multirow[t]{2}{*}{361186} \\
\hline & & & $\begin{array}{l}\text { Environmental } \\
\text { Science Q1 }\end{array}$ & & \\
\hline SCIENCE & $\begin{array}{l}\text { The United } \\
\text { States }\end{array}$ & $\begin{array}{l}\text { Comprehensive } \\
\text { Q1 }\end{array}$ & $\begin{array}{l}\text { Comprehensive } \\
\text { Q1 }\end{array}$ & 41.322 & 1380869 \\
\hline NATURE & England & $\begin{array}{l}\text { Comprehensive } \\
\text { Q1 }\end{array}$ & $\begin{array}{l}\text { Comprehensive } \\
\text { Q1 }\end{array}$ & 42.475 & 1512938 \\
\hline \multirow{3}{*}{$\begin{array}{l}\text { FUEL } \\
\text { PROCESS } \\
\text { TECHNOL }\end{array}$} & \multirow[t]{3}{*}{ Netherlands } & \multirow[t]{3}{*}{$\begin{array}{l}\text { Engineering } \\
\text { technology Q2 }\end{array}$} & $\begin{array}{l}\text { Applied chemistry } \\
\text { Q2 }\end{array}$ & \multirow[t]{3}{*}{4.482} & \multirow[t]{3}{*}{40911} \\
\hline & & & $\begin{array}{l}\text { Energy and Fuels } \\
\text { Q3 }\end{array}$ & & \\
\hline & & & $\begin{array}{l}\text { Engineering: } \\
\text { Chemical } \\
\text { Engineering Q2 }\end{array}$ & & \\
\hline \multirow[t]{2}{*}{$\begin{array}{l}\text { J HAZARD } \\
\text { MATER }\end{array}$} & \multirow[t]{2}{*}{ Netherlands } & \multirow{2}{*}{$\begin{array}{l}\text { Environmental } \\
\text { Science and } \\
\text { Ecology Q1 }\end{array}$} & $\begin{array}{l}\text { Engineering: } \\
\text { Environment Q2 }\end{array}$ & \multirow[t]{2}{*}{$7 \otimes 707$} & \multirow[t]{2}{*}{206544} \\
\hline & & & $\begin{array}{l}\text { Environmental } \\
\text { Science Q1 }\end{array}$ & & \\
\hline \multirow[t]{2}{*}{$\begin{array}{l}\text { ATMOS } \\
\text { ENVIRON }\end{array}$} & \multirow[t]{2}{*}{ England } & \multirow{2}{*}{$\begin{array}{l}\text { Environmental } \\
\text { Science and } \\
\text { Ecology Q2 }\end{array}$} & $\begin{array}{l}\text { Environmental } \\
\text { Science Q3 }\end{array}$ & \multirow[t]{2}{*}{3.92} & \multirow[t]{2}{*}{115151} \\
\hline & & & $\begin{array}{l}\text { Meteorology and } \\
\text { Atmospheric } \\
\text { Science Q2 }\end{array}$ & & \\
\hline
\end{tabular}




\begin{tabular}{|llllll|}
\hline Abbreviation & $\begin{array}{l}\text { Publishing } \\
\text { country }\end{array}$ & $\begin{array}{l}\text { Primary } \\
\text { classification }\end{array}$ & $\begin{array}{l}\text { Secondary } \\
\text { classification }\end{array}$ & $\begin{array}{l}\text { Average IF } \\
\text { (2019 2021) }\end{array}$ & $\begin{array}{l}\text { Citation } \\
\text { frequency } \\
\text { (2020- } \\
\text { 2021) }\end{array}$ \\
\hline $\begin{array}{l}\text { J LOSS } \\
\begin{array}{l}\text { PREVENT } \\
\text { PROC }\end{array}\end{array}$ & Netherlands & $\begin{array}{l}\text { Engineering } \\
\text { Technology Q3 }\end{array}$ & $\begin{array}{l}\text { Engineering: } \\
\text { Chemical } \\
\text { Engineering Q4 }\end{array}$ & 2.282 & 11964 \\
\hline
\end{tabular}

In journal co-citation, INT J COAL GEOL, FUEL, SCIENCE OF TOTAL ENVIRONMENT, ENVIRON SCI TECHNOL., SCIENCE and NATURAE are frequently cited. INT J COAL GEOL, FUEL, FUEL PROCESS TECHNOL and J LOSS PREVENT PROC belong to engineering journals. SCI TOTAL ENVIRON, ENVIRON SCI TECHNOL, J HAZARD MATER, and ATMOS ENVIRON belong to the environmental science and ecology journals, while SCIENCE and NATURE belong to the general journals. On the whole, these journals are internationally famous and widely cited, which reflects that these journals are important knowledge supply in mine fire research, and also shows the importance of these journals in this field.

\subsection{Research hotspots analysis \\ 4.6.1. Key words co-occurrence}

Keywords, representing the core and essence life-quintessence of the article, are a high-level summing-up to the article theme, so the keywords analysis examines the research focus of the papers (Zhu et al., 2021a). High frequency keywords are used to ensure the research hot pot in a certain field and 17 high frequency keywords are obtained through order statistics in mine fire research, which is listed in Table. 5. The top 10 keywords includes "spontaneous combustion", "coal", "low temperature oxidation", "fire", "oxidation", "mechanism", "temperature", "mine", "kinetics", "model”(Zhu et al., 2021a; Zhu et al., 2021b; Zhu et al., 2021c; Zhu et al., 2021d). 
Table 5

Listing of high frequency keywords

\begin{tabular}{|llll|}
\hline Number & Counts & Centrality & Keywords \\
\hline 1 & 299 & 0.05 & spontaneous combustion \\
\hline 2 & 191 & 0.05 & coal \\
\hline 3 & 190 & 0.07 & low temperature oxidation \\
\hline 4 & 148 & 0.18 & fire \\
\hline 5 & 136 & 0.07 & oxidation \\
\hline 6 & 93 & 0.01 & mechanism \\
\hline 7 & 85 & 0.01 & temperature \\
\hline 8 & 76 & 0.09 & mine \\
\hline 9 & 76 & 0.03 & kinetics \\
\hline 10 & 69 & 0.10 & model \\
\hline 11 & 68 & 0.05 & pyrolysis \\
\hline 12 & 67 & 0.08 & behavior \\
\hline 13 & 66 & 0.04 & bituminous coal \\
\hline 14 & 63 & 0.19 & prevention \\
\hline 15 & 59 & 0.03 & gas \\
\hline 16 & 56 & 0.07 & emission \\
\hline 17 & 54 & 0.08 & propensity \\
\hline
\end{tabular}

The WOS data is imported into Citespace and formatted transformation, the time span from 1998 to 2020, time slice is 1 year, "Keywords" is set as "Node Types" analysis content, and path algorithm is set as "Pathfinder" for author analysis. Thus, a keyword co-occurrence network map of "Nodes $=528$ " and "Links $=1853 "$ is obtained, as shown in Fig. 8 .

Nodes represent key words, and the number of nodes represents the key words number in the paper. The line reflects the relationship between keywords and the node size represents the keyword frequency. Centrality is one of the criteria to describe the nodes importance, indicating the possibility that a node becomes the "intermediary" of other nodes. The Citespace visual interface specializes the high intermediate centrality nodes. When the intermediate centrality is greater than 0.1 , a purple circle appears on the outside of the node's annual ring (Liu et al., 2020).

According to the node radius in the map and the order in the table, the five keywords of "Spontaneous combustion", "coal", "low temperature oxidation", "fire" and "oxidation" are cited more than 100 times, 
followed by "mechanism". "Temperature", "mine", "kinetics" and "Model" are all cited more than 50 times (Wen et al., 2017; Du et al., 2015; Yang et al., 2015; Kim et al., 2016; Wu et al., 2017).

\subsubsection{Keywords Cluster}

39 clusters are obtained from 528 keywords extraction and the main clusters are displayed in Fig. 9. According to \#0, \#1...... \#20 sort, the map covers 21 clusters from \#0 to \#20. \#0 india冈\#1 model囚\#2

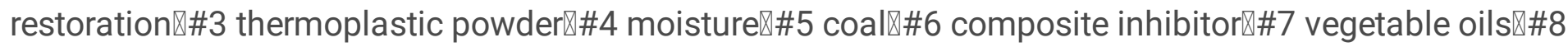
gas $\# 9$ fine particulate matter $\# 10$ product $\# 11$ coal stockpile $\# 12$ mechanical thermal expression $\# 13$ carbon nanotubes $₫ \# 14$ discrimination $\rrbracket \# 15$ coalfield $\# \# 16$ emergency rescue $\# 17$ forest burned areas $\sharp 18$ emission囚\#19 threatened species囚\#20 foam stability (Jolanta et al., 2017; Qin et al., 2017; Jo et al., 2015; Qin et al., 2016; Lu et al., 2017).

Modularity Q and Mean Silhouette S are two indicators reflecting the definition of cluster boundary and cluster size. In the map, Modularity Q $=0.8057(Q>0.3)$ indicates clear boundaries between research topics and significant field differentiation. Mean Silhouette $S=0.91(S>0.7)$ with good clustering effect. The labels and related descriptions of each cluster are shown in Table. 6 and Table. 7. 
Table 6

Keywords cluster statistical analysis

\begin{tabular}{|c|c|c|c|c|}
\hline Cluster & Keywords & Size & Silhouette & Mean year \\
\hline$\# 0$ & india & 48 & 0.905 & 2010 \\
\hline \#1 & model & 41 & 0.806 & 2010 \\
\hline \#2 & restoration & 40 & 0.941 & 2005 \\
\hline \#3 & thermoplastic powder & 30 & 0.975 & 2015 \\
\hline \#4 & moisture & 29 & 0.929 & 2006 \\
\hline \#5 & coal & 28 & 0.855 & 2013 \\
\hline \#6 & composite inhibitor & 27 & 0.836 & 2016 \\
\hline \#7 & vegetable oils & 27 & 0.994 & 2009 \\
\hline$\# 8$ & gas & 26 & 0.894 & 2011 \\
\hline \#9 & fine particulate matter & 25 & 0.886 & 2016 \\
\hline \#10 & product & 24 & 0.876 & 2010 \\
\hline \#11 & coal stockpile & 23 & 0.817 & 2011 \\
\hline$\# 12$ & mechanical thermal expression & 21 & 1.000 & 2009 \\
\hline$\# 13$ & carbon nanotubes & 20 & 0.877 & 2016 \\
\hline$\# 14$ & discrimination & 20 & 0.965 & 2012 \\
\hline \#15 & coalfield & 17 & 0.94 & 2006 \\
\hline \#16 & emergency rescue & 14 & 0.989 & 2012 \\
\hline$\# 17$ & forest burned areas & 14 & 0.913 & 2012 \\
\hline \#18 & emission & 10 & 0.996 & 2013 \\
\hline \#19 & threatened species & 8 & 1.000 & 2010 \\
\hline \#20 & foam stability & 6 & 0.983 & 2015 \\
\hline
\end{tabular}


Table 7

Keywords cluster information table

\section{Cluster Top terms}

\#0 spontaneous combustion; plugging property; temperature; mine fire; india; temperature; impact; mine fire; india; area; india; coal fire; jharia coalfield; wuda; aster.

\#1 spontaneous combustion; activation energy; thermal analysis; analytical solution; ignition behavior; low temperature; self -heating; safety engineering; proactive inertisation; mine safety; model; low temperature oxidation; aliphatic hydrocarbon; unsaturated hydrocarbons; proactive inertisation.

\#2 spontaneous combustion; situ fourier; surface characteristics; infrared spectroscopy; grey correlation analysis; low-temperature oxidation; functional group; inhibiting effect; thermal release intensity; thermogravimetric analysis; product; initial exothermic temperature; element occurrence; methane migration; surface characteristics.

\#3 spontaneous combustion; free radical reaction; porosity changes; porous media; gangue hill; coal stockpile; temperature profile; coal oxidation; thermoplastic powder; extinguishing fire; coal stockpile; prevention; goaf; statistical model.

\#4 spontaneous combustion; mechanical thermal expression; particle size; mineral matters; pore structure; forest fire; historical mining; environmental pollution; prescribed fire; water pollution; mechanical thermal expression; forest fire; lignite; prescribed fire; ash.

\#5 spontaneous combustion; emission regularity; co-generation mechanism; advanced characterization; iron nanoparticles; carbon nanotubes; rare earth elements; colombian coals; spontaneous coal; analytical approach; carbon nanotubes; potential hazardous elements; nano-minerals; human exposure; advanced characterization.

\#6 spontaneous combustion; inhibition characteristic; particle size; crustal structure; foaming agent; discrimination; crustal structure; quarry; anisotropy; mining explosion; discrimination; explosion; quarry blast; earthquake; daxing mine.

\#7 spontaneous combustion; bi-point source; reverse dispersion modelling; emission factor; fire extinguishment; coalfield; coal fire; natural example; in situ gasification; depth; coalfield; depth; east basuria colliery; coal fire; back-calibration.

numerical simulation; emergency rescue; smoke plume control; porous media; critical velocity; porous media; coal stockpile; natural convection; convection visualization; cooling area; emergency rescue; fds; cfd; porous media; numerical simulation.

\#9 table mountain; pinus pungens; appalachian mountains; fire history; satellite data; forest fire; metal contamination; post-mining environment; water quality; mining disturbance; forest burned areas; gas chromatography-mass spectrometry (gc-ms); africa; serpentine barren; pinus virginiana.

\#10 spontaneous combustion; underground coal mine; ambient temperature; toxicity; gangue hill; emission; toxicity; sampler; partition coefficient; deposition; emission (14.45, 0.001); pah; fluorine release; microbial remediation.

\#11 bauxite mining; vegetation structure; tropical savannas; new caledonia; ultramafic substrates; new caledonia; ultramafic substrates; tropical savannas; bauxite mining; vegetation structure; threatened species; conifers; tropical savannas; ultramafic substrates; new caledonia. fire; rehabilitation; savanna; fuel; minesite; restoration; fire; mining; lampropholis; reptile. 


\begin{tabular}{|ll|}
\hline Cluster & Top terms \\
\hline \#13 & $\begin{array}{l}\text { spontaneous combustion; carbon dioxide; temperature-sensitive retardant microcapsule; } \\
\text { fire-retardant mechanism; coal mine fires; tendency; mathematical origin; coal spontaneous } \\
\text { combustion; sulfide mineral; powder; foam stability; kinetic based simulation method; three- } \\
\text { phase foams; mathematical origin; powder. }\end{array}$ \\
\#14 & $\begin{array}{l}\text { spontaneous combustion; clay suspensions; alginate fluid gels; ash content; coal mining; } \\
\text { thermoplastic powder; extinguishing fire; oxygen consumption; polymorphic foam clay; coal } \\
\text { self-oxidation; thermoplastic powder; inert gas; flame retardant; convection; synergistic } \\
\text { effect. }\end{array}$ \\
spontaneous combustion; apparent activation energy; differential scanning calorimetry; \\
mechanism function; particle size; low-temperature oxidation; functional group; cyclic \\
reaction; oxidation; moisture; moisture; inversion temperature; crossing-point temperature; \\
self-ignition; drying.
\end{tabular}

\subsubsection{Burst term map}

Using the Burstdetection algorithm, the words with high frequency change rate in the subject words are detected from a large number of subject words as burst term. Combined with the change trend of word frequency, it predicts the research frontier and development trend of mine fire. In Citespace, burst term is refined with the parameter Y (range 0-1) of BURSTNESS. Generally, the breakout values can be easily found on the interface with a low $y$ value, as shown in Table. 8 . When the parameter is set to $y=0.9$, a total of 25 emergent words are displayed, as shown in Fig. 10 in chronological order. 
Table 8

Parameter y Value range

\begin{tabular}{|llll|}
\hline Y value & Burst term number & Yvalue & Burst term number \\
\hline 0.1 & 129 & 0.6 & 53 \\
0.2 & 127 & 0.7 & 40 \\
0.3 & 126 & 0.8 & 30 \\
0.4 & 99 & 0.9 & 25 \\
\hline 0.5 & 69 & 1.0 & 10 \\
\hline
\end{tabular}

The highest burst intensity is "coal", which started in 2000 and decreased sharply in 2015. Around 2000, the world entered the rapid economic development stage, coal was widely used for heating, iron smelting, oil refining and other aspects, gradually infiltrated into the national defense, industry, agriculture, medicine and other industries, so the world increased the mining of coal. With the excessive use of coal, the global temperature has deteriorated and heated up, causing great damage to the world's ecological environment. In 2003, the concept of "low-carbon economy" emerged to reduce energy consumption and carbon dioxide emissions, so as to resist climate change. The time of "coal" surge and stabilization keeps pace with the hot spot time of international coal policy. This indicates that the burst term intensity is influenced by the political and economic environment at that time and is closely related to relevant policies.

\section{Conclusion}

According to the published papers number, the research on mine fire can be divided into three stages: initial period (1999-2005), stable transition period (2005-2014), and vigorous growth period (2014-2020), with an overall upward trend.

In terms of research subjects, DENG J from Xi 'an University of Science and Technology in China ranks the top in the 67 prolific authors. In addition, Chinese authors occupy an increasing proportion in this field. There are many scholars studying mine fire in the world, but most of their researches are scattered and there is no large-scale cooperation and communication

From the research space, China Univ Min \& Technol ranks first among high-yield institutions, and the cooperation between institutions is mainly in neighboring regions. There is also a strong regional distribution in the cooperation among countries, with China, the United States and Australia as the center of the cooperation network. The countries where the high-yield institutions are located have made significant contributions to the research on mine fire.

Based on the research knowledge, INT J COAL GEOL and FUEL are the most influential journals in COAL, and the paper published in the two journals have strong influence and recognition. Cheng WM, 2017, FUEL, V210, P826, DOI 10.1016/j.fuel.2017.09.007 is the highest cited papers. After 2015, the content of paper is more convincing, accounting for $90 \%$ of highly cited paper. 
With the research hotspots, mine fire mainly involves basic research fields such as coal spontaneous combustion, goaf fire and low temperature oxidation. Affected by the economic and political environment at that time, the research hotspot lasts for at least two years, accompanied by the emergence and sharp decline of burst term. It is speculated that the research will focus on fire prevention, low carbon, ecology and sustainable development in this field.

\section{Declarations}

\section{Ethical Approval}

Not applicable.

\section{Consent to Participate}

Not applicable.

\section{Consent to Publish}

Not applicable.

\section{Authors Contributions}

Feiran Wang: Formal analysis, Writing-original draft, Visualization. Bo Tan: Methodology, Conceptualization, Writing-review \& editing. Yue Chen: Writing-original draft, Visualization. Xiyang Fang: Formal analysis, Visualization. Guowei Jia: Investigation. Haiyan Wang: Methodology, Conceptualization, Writing-review \& editing. Gang Cheng: Investigation. Zhuangzhuang Shao: Investigation.

\section{Funding}

Funding: This work was supported by the financial support of the National Nature Science Foundation of China (52074156 and 51804355).

\section{Competing interest}

The authors declare no conflict of interest.

\section{Availability of data and materials}


The data and materials used to support the findings of this study are available from the corresponding author upon request.

\section{References}

1. Cai JW, Yang SQ, Hu XC, Song WX, Xu Q, Zhou BZ, Song YW (2019) Forecast of coal spontaneous combustion based on the variations of functional groups and microcrystalline structure during lowtemperature oxidation. Fuel 253:339-348

2. Cai JW, Yang SQ, Zheng WC, Song WX (2021) Rajender, G. Dissect the capacity of low-temperature oxidation of coal with different metamorphic degrees. Fuel 292:120256

3. Chen Y, Chen CM, Liu ZY, Hu ZG, Wang XW (2015) The methodology function of Citespace mapping knowledge domains. Studies in Science of Science 33:242-253

4. Cui X, Wang JH, Li J (2019) Analysis of knowledge graph of poor fire research with CiteSpace. Fire Science and Technology 38:1618-1623

5. Deng J, Xiao Y, Li QW, Lu JH, Wen H (2015) Experimental studies of spontaneous combustion and anaerobic cooling of coal. Fuel 157:261-269

6. Deng J, Zhao JY, Zhang YN, Huang AC, Liu XR, Zhai XW, Wang CP (2016) Thermal analysis of spontaneous combustion behavior of partially oxidized coal. Process Saf Environ Prot 104:218-224

7. Deng J, Li QW, Xiao Y, Shu CM (2017a) Experimental study on the thermal properties of coal during pyrolysis, oxidation, and re-oxidation. Appl Therm Eng 110:1137-1152

8. Deng J, Zhao JY, Huang AC, Zhang YN, Wang CP, Shu CM (2017b) Thermal behavior and microcharacterization analysis of second-oxidized coal. J Therm Anal Calorim 127:439-448

9. Deng J, Yang Y, Zhang YN, Liu B, Shu CM (2018) Inhibiting effects of three commercial inhibitors in spontaneous coal combustion. Energy 160:1174-1185

10. Du XM, Peng SP, Wang HY, Bernardes S, Yang G, Li ZP (2015) Annual Change Detection by ASTER TIR Data and an Estimation of the Annual Coal Loss and CO2 Emission from Coal Seams Spontaneous Combustion. Remote sensing 7:319-341

11. Du WZ, Wang Y, Liu XL, Sun LL (2018) Study on Low Temperature Oxidation Characteristics of Oil Shale Based on Temperature Programmed System. Energies 11:2594

12. Fu XL, Han JT, Li M (2020) Visualized analysis on forest fire research paper based on Citespace. Anhui Forestry Science and Technology 46:56-61

13. He CY, Liu YX, Li CY, Jia N, Zhang P (2019) Visual analysis of studies on the simulation of fire based on knowledge graph. Fire Science and Technology 38:1615-16171623

14. Jin RY, Zou Patrick XW, Poorang P, Hannah W, Yang Y, Yan LB, Han Y (2019) A Science Mapping Approach Based Review of Construction Safety Research. Saf Sci 113:285-297

15. Jo W, Choi H, Kim S, Yoo J, Chun D, Rhim Y, Lim J, Lee S (2015) Changes in spontaneous combustion characteristics of low-rank coal through pre-oxidation at low temperatures. Korean $\mathrm{J}$ Chem Eng $32: 255-260$ 
16. Jolanta K, Magdalena MK, ICCP (2017) Coal weathering and laboratory (artificial) coal oxidation. Int J Coal Geol 171:12-36

17. Kim KJ, Chang CH, Ahn HG (2016) The Effect of Zinc Oxide Addition to Alumina-Supported Gold Catalyst in Low Temperature Carbon Monoxide Oxidation. J Nanosci Nanotechnol 15:660-664

18. Lee DG, Isworo YY, Park KH, Kim GM, Kim SM, Jeon CH (2020) Low-Temperature Oxidation Reactivity of Low-Rank Coals and Their Petrographic Properties. ACS OMEGA 5:18594-18601

19. Li F, Li JL, Liu XY, Meng XL (2020) Coal fire detection and evolution of trend analysis based on CBERS-04 thermal infrared imagery. Environ Earth Sci 17:384

20. Li J (2016) Science structure and topics evolution of safety. Capital University of Economics and Business

21. Lin Y (2020) Knowledge map analysis of FDS fire simulation based on Citespace. Journal of the Armed Police Academy 36:15-19

22. Liu H, Hong R, Xiang CL, Lv C, Li HH (2020) Visualization and analysis of mapping knowledge domains for spontaneous combustion studies. Fuel 262:116598

23. Liu JH, Li J, Fan CG (2020) A bibliometric study of pool fire related publications. J Loss Prev Process Ind 63:104030

24. Liu SH, Shu CM, Hou HY (2015) Applications of thermal hazard analyses on process safety assessments. J Loss Prev Process Ind 33:59-69

25. Liu XN (2020) A Visualization Analysis on Researches of Internet Finance Credit Risk in Coastal Area. J Coastal Res 103:85-89

26. Lu XX, Han Y, Xue X, Wang DM (2019) Research on a noble extinguish material for the underground fire prevention. Fire Mater 44:230-241

27. Lu W, Cao YJ, Huang ZA, Tien JC, Qin BT (2017) Study on Adiabatic Oxidation Characters of Coal with Applying a Constant Temperature Difference To Guide the Oxidation of Coal with Temperature Rising. Energy\& Fuels 31:882-890

28. Lu W, Zhang XD, Yuan Y, Qi GS, Hu XM, Li JL, Liang YT, Guo BL (2021) Study on the characteristics and mechanism of a new type of antioxidant gel foam for coal spontaneous combustion prevention. Colloids Surf, A 628:127254

29. Luo ZZ, Qin BT, Shi QL, Hu HJ, Sheng P, Tian SY (2022) Colloids and Surfaces A: Physicochemical and Engineering Aspects. Fuel 308:121999

30. Ma LY, Wang DM, Wang Y, Dou GL, Xin HH (2017) Synchronous thermal analyses and kinetic studies on a caged-wrapping and sustained-release type of composite inhibitor retarding the spontaneous combustion of low-rank coal. Fuel Process Technol 157:65-75

31. Pan RK, Hu DM, Chao JK, Wang L, Ma JW, Jia HL (2020) The heat of wetting and its effect on coal spontaneous. Thermochimica acta 691:178711

32. Qin BT, Dou GL, Wang DM (2016) Thermal Analysis of Vitamin C Affecting Low-temperature Oxidation of Coal. Journal of Wuhan University of Technology-Materials Science Edition 31:519-522 
33. Qin BT, Dou GL, Wang Y, Xin HH, Ma LY, Wang DM (2017) A superabsorbent hydrogel-ascorbic acid composite inhibitor for the suppression of coal oxidation. Fuel 190:129-135

34. Qin BT, Dou GL, Zhong XX (2018) Effect of stannous chloride on low-temperature oxidation reaction of coal. Fuel Process Technol 176:59-63

35. Shao ZL, Jia XY, Zhong XX, Wang DM, Wei J, Wang YM, Chen L (2018) Detection, extinguishing, and monitoring of a coal fire in Xinjiang, China. Environ Sci Pollut Res 25:26603-26616

36. Sun Y, Wang SG, Wei L, Cao YJZ, Li JL (2019) Coal spontaneous combustion characteristics based on constant temperature difference guidance method. Process Saf Environ Prot 131:223-234

37. Song YW, Yang SQ, Xu Q, Cai JW, Hu XC, Sang NW, Zhang ZC (2019) Effect of low-temperature oxidation of coal with different metamorphic degrees on coal quality characteristics and outburst comprehensive index. Process Saf Environ Prot 132:142-152

38. Tan B, Zhang FC, Zhang QS, Wei HY, Shao ZZ (2019) Firefighting of subsurface coal fires with comprehensive techniques for detection and control: a case study of the Fukang coal fire in the Xinjiang region of China. Environ Sci Pollut Res 26:29570-29584

39. Tan B, Cheng G, Zhu XM, Yang XB (2020a) Experimental Study on the Physisorption Characteristics of 02 in Coal Powder are Effected by Coal Nanopore Structure. Sci Rep 10:6946

40. Tan B, Liu HL, Xu B, Wang T (2020b) Comparative study of the explosion pressure characteristics of micro- and nano-sized coal dust and methane-coal dust mixtures in a pipe. International Journal of Coal Science \& Technology 7:68-78

41. Tan B, Wei HY, Zhang FC, Xu B, Chen KL (2020c) Effect of inhibitors on the thermodynamics and kinetics of s.pontaneous combustion of coal. J Therm Anal Calorim 140:295-307

42. Wang CP, Yang Y, Tsai YT, Deng J, Shu CM (2016) Spontaneous combustion in six types of coal by using the simultaneous thermal analysis-Fourier transform infrared spectroscopy technique. $J$ Therm Anal Calorim 126:1591-1602

43. Wang CX, Lv SR (2016) Visualization analysis on research status, hotspots and fronts in gas explosion area in China. Fire Science and Technology 35:1620-1623

44. Wen H, Yu ZJ, Fan SX, Zhai XW, Liu WY (2017) Prediction of Spontaneous Combustion Potential of Coal in the Gob Area Using CO Extreme Concentration: A Case Study. Combust Sci Technol 189:1713-1727

45. Wen H, Wang H, Liu WY, Cheng XJ (2020) Comparative study of experimental testing methods for characterization parameters of coal spontaneous combustion. Fuel 275:117880

46. Wu JW, Chen J, Guo Q, Dai DX, Yang XM (2017) Low-temperature CO oxidation on Co (0001). Chem Phys Lett 683:633-638

47. Xue WZ, Li H, Rizwan A, Ramiz Ur ORCID R (2020) Knowledge Mapping of Corporate Financial Performance Research: A Visual Analysis Using Cite Space and Ucinet. Sustainability 12:35-54

48. Xiao Y, Ren SJ, Deng J, Shu CM (2018) Comparative analysis of thermokinetic behavior and gaseous products between first and second coal spontaneous combustion. Fuel 227:325-333 
49. Xu JG, Li MY, Gao Y, Liu M, Shi SZ, Shi JY, Yang KL, Zhou Z, Tian JH (2021) Using Mendelian randomization as the cornerstone for causal inference in epidemiology. Environ Sci Pollut Res. https://doi.org/10.1007/s11356-021-15939-3

50. Xu Q, Yang SQ, Hu XC, Song WX, Cai JW, Zhou BZ (2019) Low-temperature oxidation of free radicals and functional groups in coal during the extraction of coalbed methane. Fuel 239:429-436

51. Yan ZH, Wang DD, He RX, Li N, Zhou HC, Wang YF, Song YM, Zhi KD, Teng YY, Liu QS (2019) Microstructural characteristics of Shengli lignite during low-temperature oxidation and promotion effect of iron species. Fuel 255:115830

52. Yang YP, Xu C, Xu G, Han Y, Fang YX, Zhang DK (2015) A new conceptual cold-end design of boilers for coal-fired power plants with waste heat recovery. Energy Conv Manag 89:137-146

53. Yuan S, Liu JZ, Wu JH, Zhou QQ, Wang ZH, Zhou JH, Cen KF (2018) Changes in the physicochemical characteristics and spontaneous combustion propensity of Ximeng lignite after hydrothermal dewatering. Can J Chem Eng 96:2387-2394

54. Zhang D, Yang XS, Deng J, Wen H, Xiao Y, Jia H (2021) Research on coal spontaneous combustion period based on pure oxygen adiabatic oxidation experiment. Fuel 288:119651

55. Zhang YN, Chen L, Deng J, Zhao JY, Li HT, Yang H (2019) Influence of granularity on thermal behavior in the process of lignite spontaneous combustion. J Therm Anal Calorim 135:2247-2255

56. Zhao JY, Deng J, Wang T, Song JJ, Zhang YN, Shu CM, Zeng Q (2019) Assessing the effectiveness of a high-temperature-programmed experimental system for simulating the spontaneous combustion properties of bituminous coal through thermokinetic analysis of four oxidation stages. Energy 169:587-596

57. Zhou BZ, Yang SQ, Jiang XY, Cai JW, Xu Q, Song WX, Zhou QC (2021) The reaction of free radicals and functional groups during coal oxidation at low temperature under different oxygen concentrations. Process Saf Environ Prot 150:148-156

58. Zhu EY, Qi QY, Sha M (2021) Identify the effects of urbanization on carbon emissions (EUCE): a global scientometric visualization analysis from 1992 to 2018. Environ Sci Pollut Res 28:3135831369

59. Zhu HQ, Zhao HR, Wei HY, Wang W, Wang HR, Li K, Lu XX, Tan B (2016) Investigation into the thermal behavior and FTIR micro-characteristics of re-oxidation coal. Combust Flame 216:354-368

60. Zhu HQ, Zhang YL, Qu BL, Liao Q, Wang HR, Gao RX (2021a) Thermodynamic characteristics of methane adsorption about coking coal molecular with different sulfur components: Considering the influence of moisture contents. J Nat Gas Sci Eng 94:104053

61. Zhu HQ, Fang SH, Huo YJ, Liao Q, Hu LT, Zhang YL, Li F (2021b) Study on the optimal position of the roof low roadway based on the response surface methodology. Sci Rep 11:14508

62. Zhu HQ, Guo S, Xie YY, Zhao HR (2021c) Molecular simulation and experimental studies on $\mathrm{CO} 2$ and N2 adsorption to bituminous coal. Environ Sci Pollut Res 28:15673-15686

63. Zhu HQ, Wang HR, Wei HY, Zhao HR (2021d) Study on the influence of mining conditions on the occurrence law of $\mathrm{CO}$ in coal seams with low metamorphic grade. Energy Sour Part A Recover 
Utilization Environ Eff 43:2267-2280

64. Zuo ZL, Cheng JH, Guo HX, Li YL (2021) Knowledge mapping of research on strategic mineral resource security: A visual analysis using CiteSpace. Resour Policy 74:102372

\section{Figures}

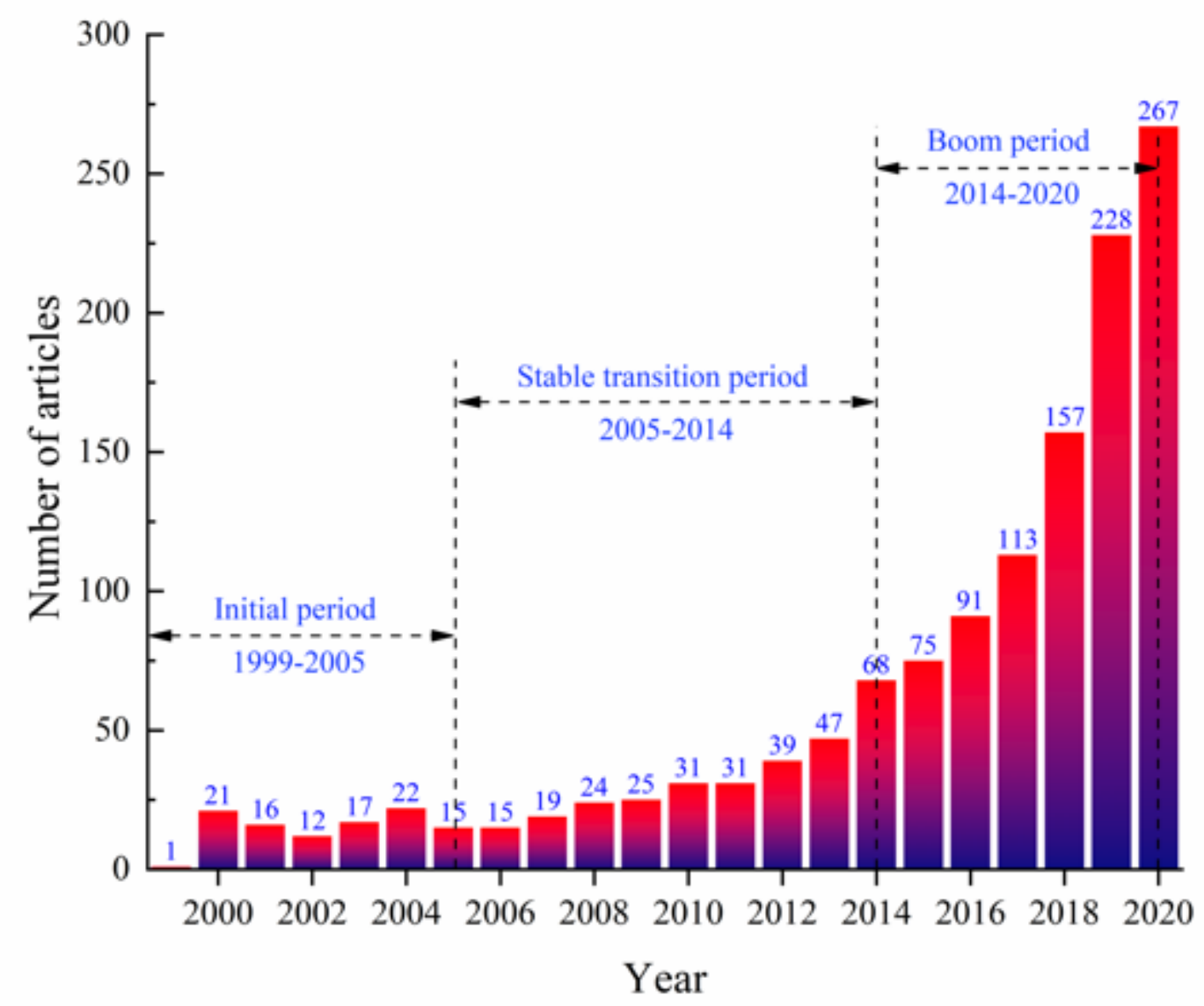

Figure 1

Chronological distribution of mine fire dispatch 
XIAOWEI ZHAI

HU WEN

LAIWANG BIN

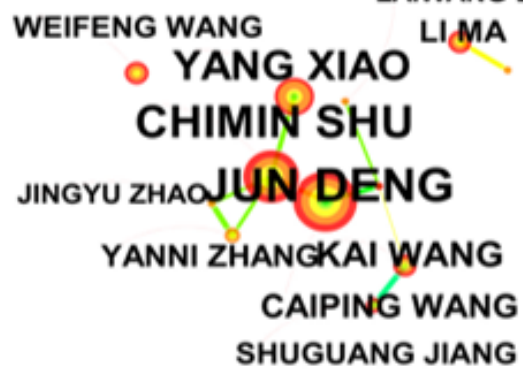

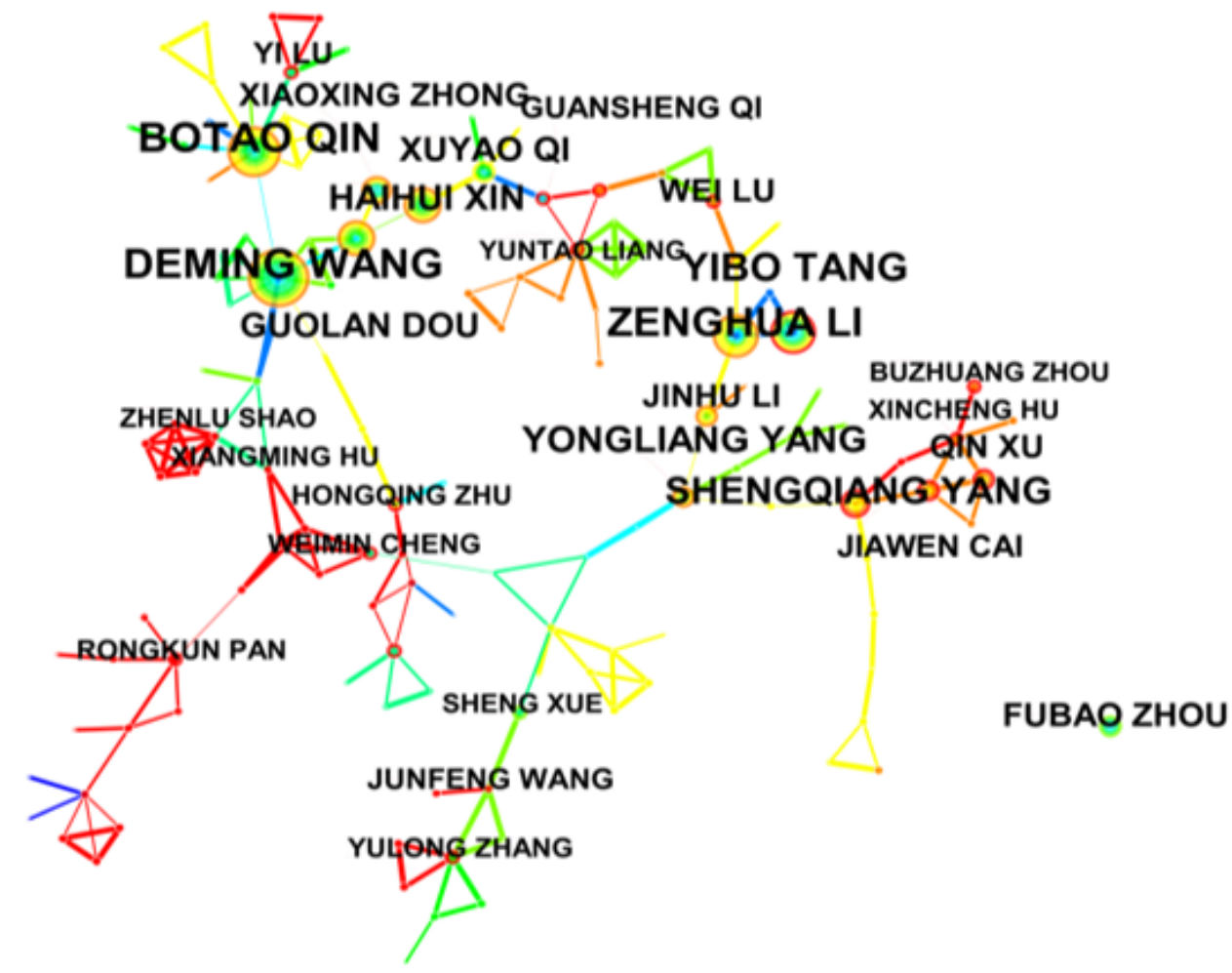

Figure 2

Author cooperation relationship map

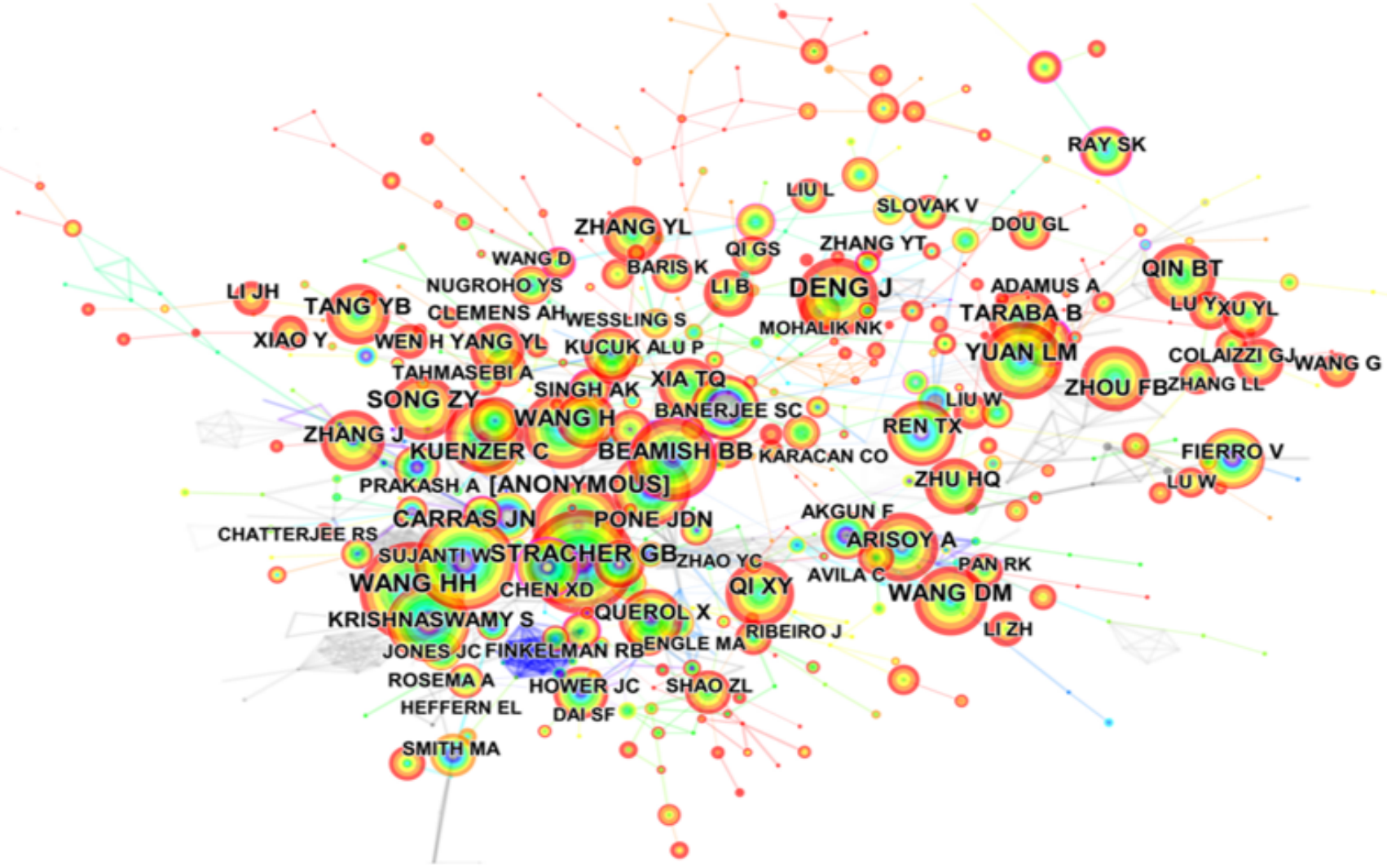


Figure 3

The authors co-citation map

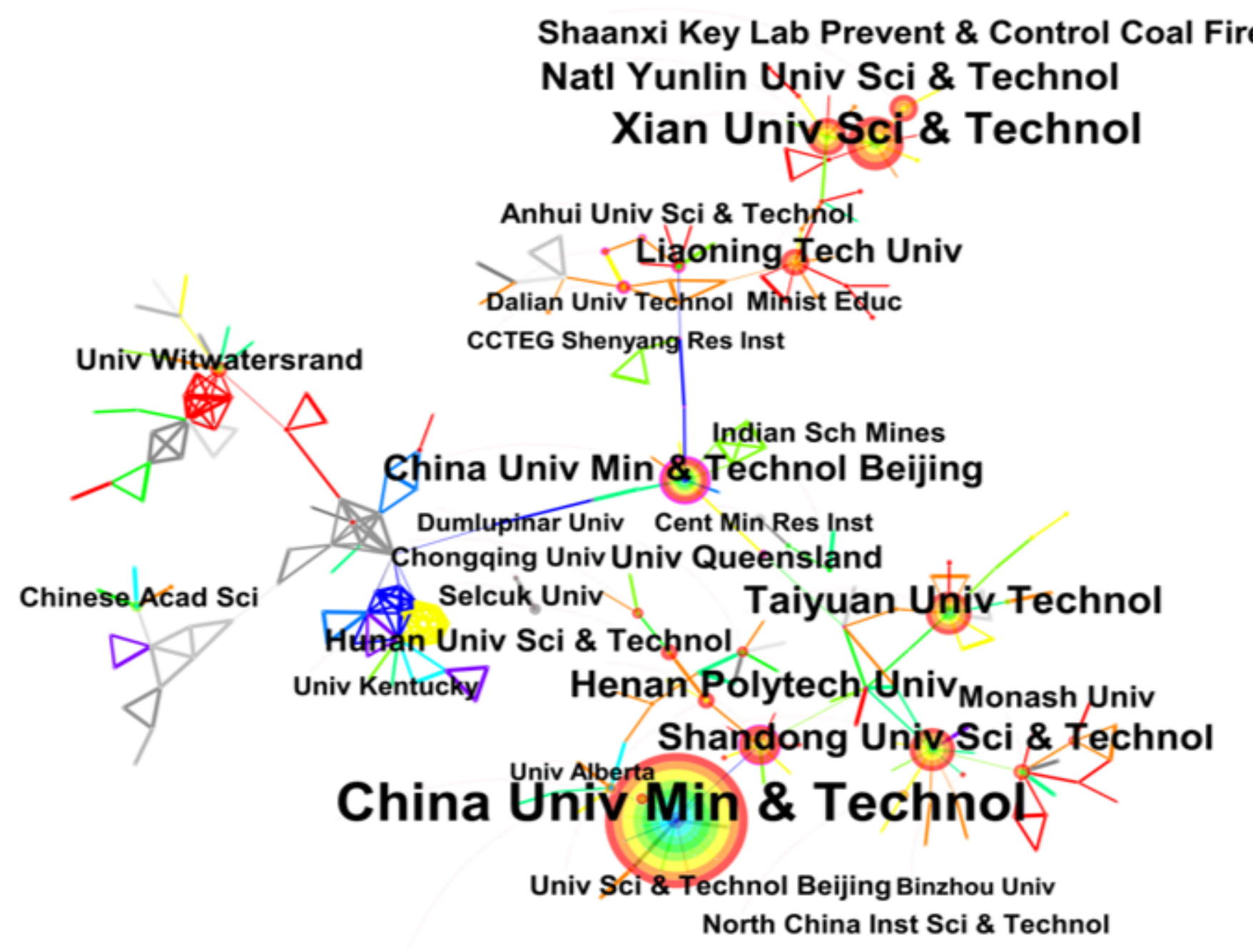

Figure 4

Cooperation relationship map of institutions and cooperative network

Figure 5

Comparison of the paper number between China and the US 


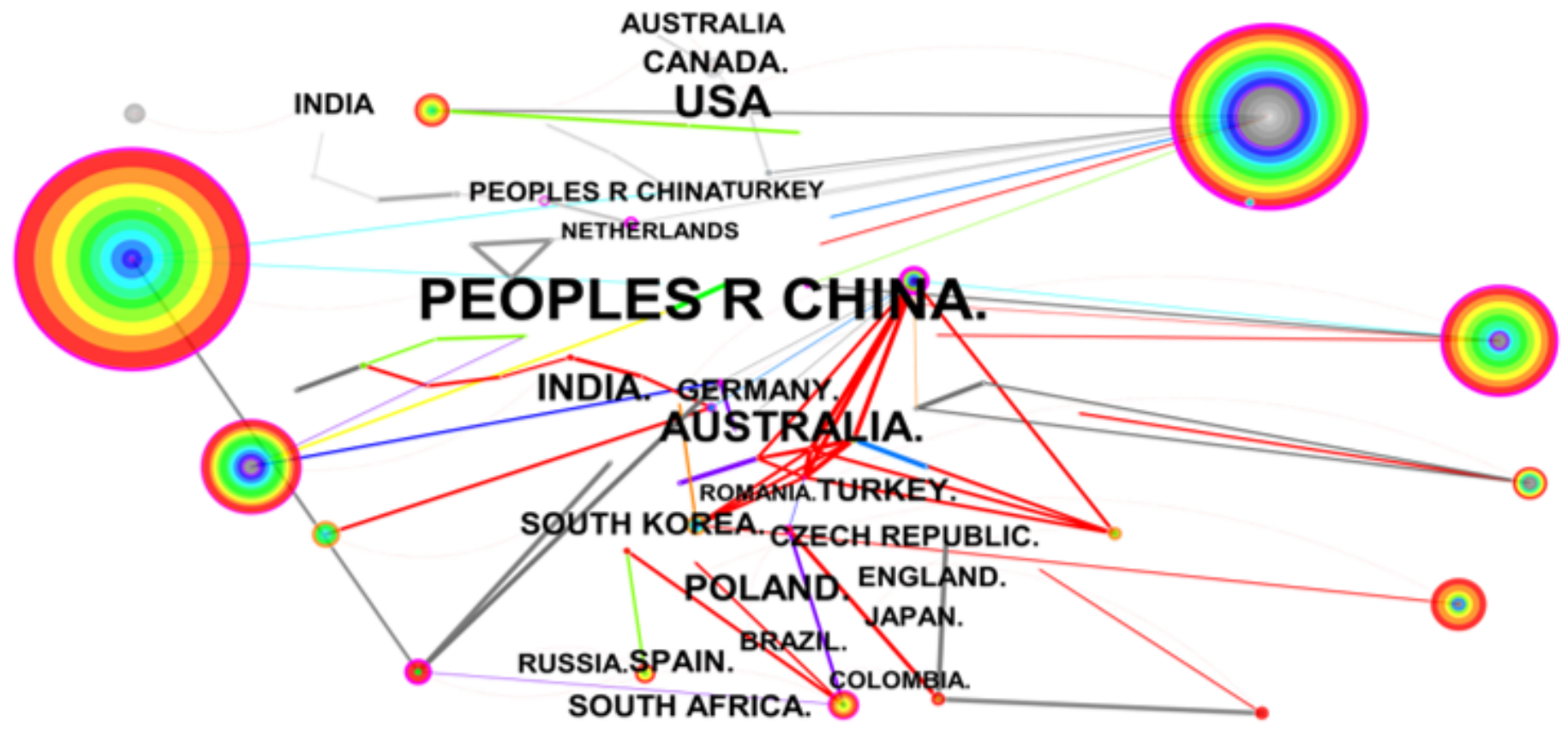

Figure 6

A network of country cooperation relationship

$$
\begin{aligned}
& \text { ENERG CONVERS MANAGE } \\
& \text { ENERGY } \\
& \text { SAFETY SCI } \\
& \text { COMBUST SCI TECHNOL }
\end{aligned}
$$

INT J MIN SCI TECHNO

POWDER TECHNOL

PROCEDIA ENGINEER J THERM ANAL CALORIMNT J HEAT MASS TRAN

J NAT GAS SCI ENGFIRE TECHNOL PROCESS SAF ENVIRON

THERMOCHIM ACTAENERG FUELAPPL THERM ENG

ENVIRON SCI POLLUT R FUEL PROCESS TECHNOL

J HAZARD MATER FUELPROG ENERG COMBUST

INT J COAL GEOL FIRE SAFETY J

INT J ROCK MECH MINJ LOSS PREVENT PROC INT J COAL PREP UTIL

NAT HAZARDS COMBUST FLAME

SCI TOTAL ENVIRONTHESIS

J CHINA COAL SOC

ATMOS ENVIRON

Figure 7 


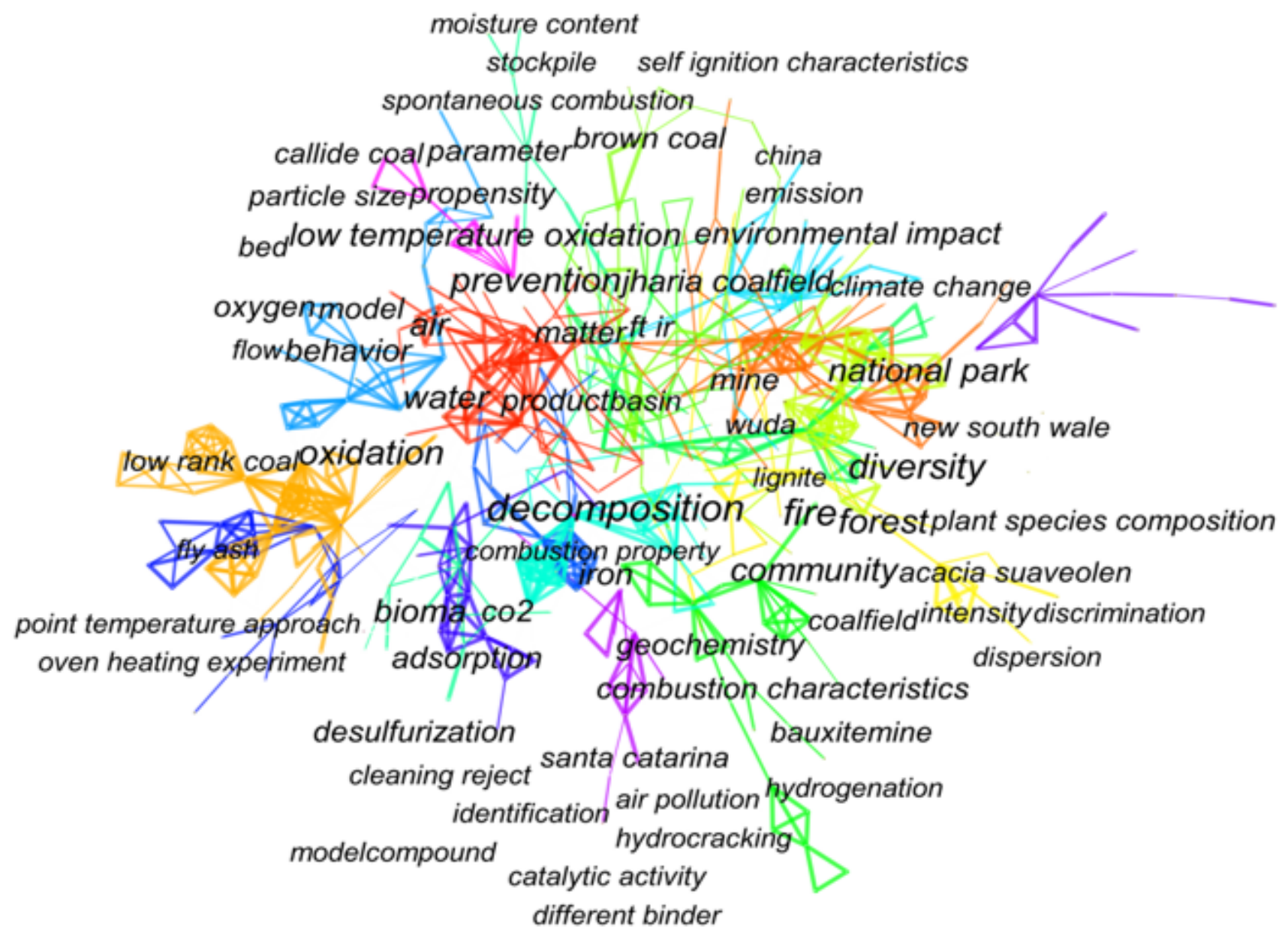

Figure 8

Keywords co-occurrence map 


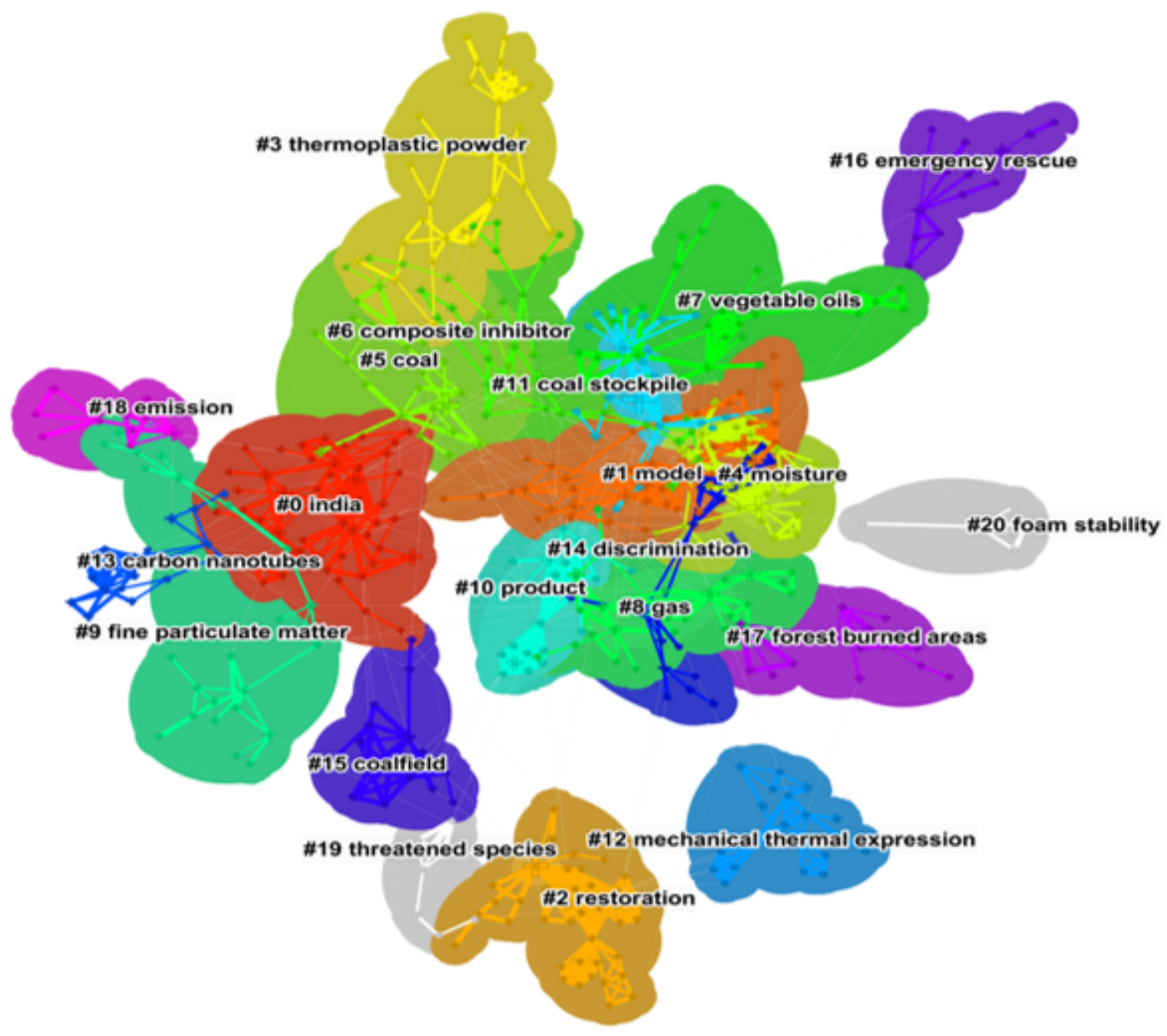

Figure 9

Keywords cluster analysis map 


\section{Top 25 Keywords with the Strongest Citation Bursts}

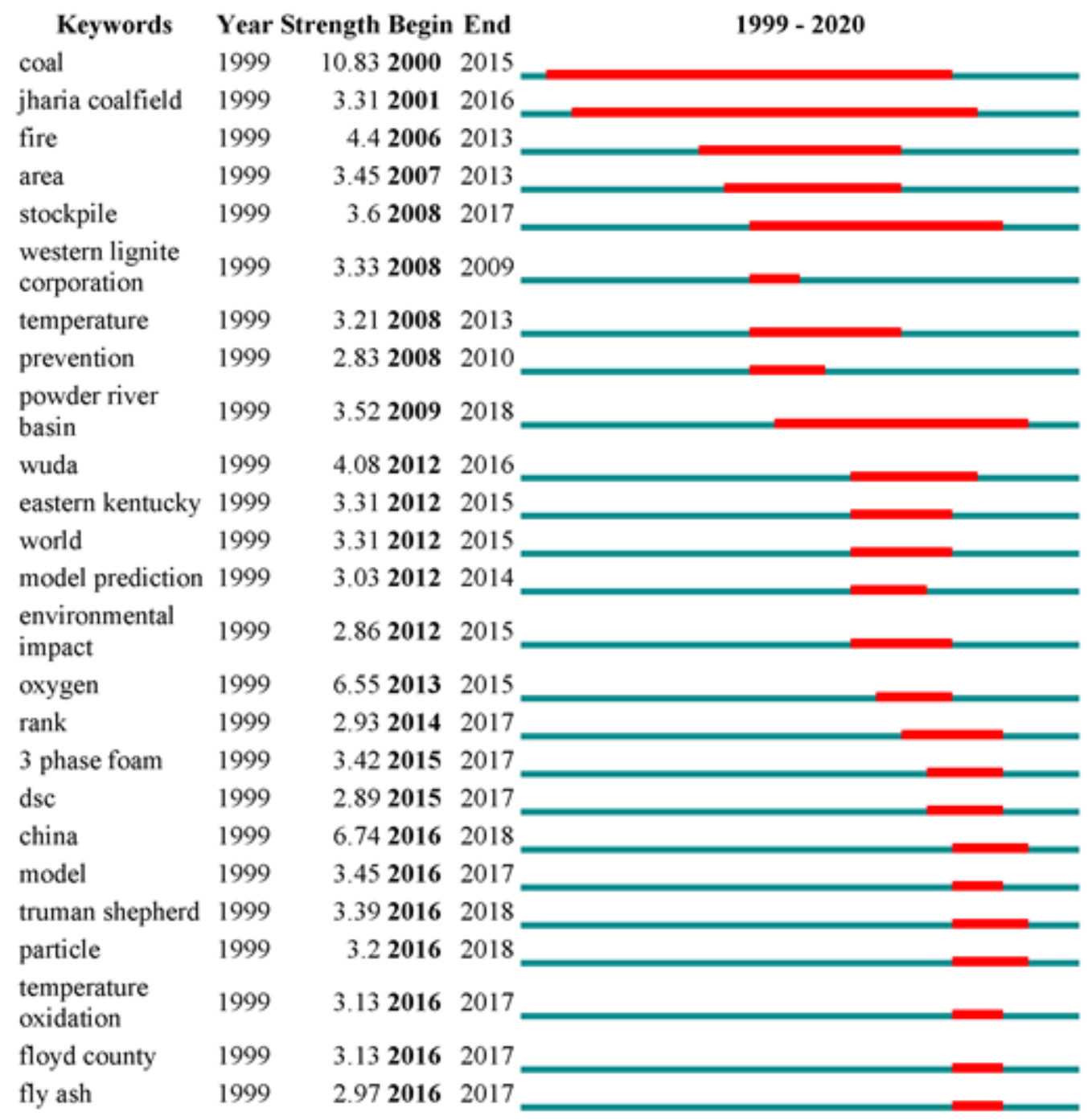

Figure 10

Keywords burst time analysis diagram 